\title{
A classification scheme for deep seafloor habitats
}

\author{
H. Gary GREENE ${ }^{\mathrm{a}}$, Mary M. YOKLAVICH ${ }^{\mathrm{b}}$, Richard M. STARR ${ }^{\mathrm{c}}$, Victoria M. O'CONNELL ${ }^{\mathrm{d}}$, \\ W. Waldo WAKEFIELD ${ }^{\mathrm{e}, \mathrm{g}}$, Deidre E. SULLIVAN ${ }^{\mathrm{f}}$, James E. McREA Jr. ${ }^{\text {a }}$, Gregor M. CAILLIET ${ }^{\text {a }}$ \\ ${ }^{a}$ Moss Landing Marine Laboratories, P.O. Box 450, Moss Landing, CA 95039, USA \\ ${ }^{b}$ NOAA National Marine Fisheries Service, Pacific Fisheries Environmental Laboratory, 1352 Lighthouse Avenue, \\ Pacific Grove, CA 93950-2097, USA \\ ${ }^{c}$ University of California Sea Grant Extension Program, P.O. Box 440, Moss Landing, CA 95039, USA \\ ${ }^{d}$ Alaska Department of Fish and Game, CFMD, 304 Lake Street, Rm. 103, Sitka, AK 99835-7563, USA \\ ${ }^{\text {e} I n s t i t u t e ~ o f ~ M a r i n e ~ a n d ~ C o a s t a l ~ S c i e n c e s, ~ R u t g e r s ~ U n i v e r s i t y, ~ C o o k ~ C a n m p u s, ~ N e w ~ B r u n s w i c k, ~ N J ~ 08901, ~ U S A ~}$ \\ ${ }^{\mathrm{f}}$ Monterey Peninsula College, Monterey, CA 93940, USA \\ \& Present addrcss: NOAA National Marinc Fisherics Scrvicc, Northwest Fisherics Science Centcr, 2030 S. \\ Marine Science Drive, Newport, OR 97365, USA
}

Revised 28 April 1999; accepted 30 April 1999

\begin{abstract}
A standard, universally useful classification scheme for deepwater habitats needs to be established so that descriptions of these habitats can be accurately and efficiently applied among scientific disciplines. In recent years many marine benthic habitats in deep water have been described using geophysical and biological data. These descriptions can vary from one investigator to another, which makes it difficult to compare habitats and associated biological assemblages among geographic regions. Using geophysical data collected with a variety of remote sensor systems and in situ biological and geologic observations, we have constructed a classification scheme that can be used in describing marine benthic habitats in deep water. (1) 1999 Ifremer / CNRS / IRD / Éditions scientifiques et médicales Elsevier SAS
\end{abstract}

\section{habitat / universal classification / benthic / fisheries management}

Résumé - Une classification des habitats benthiques profonds. Un système de classification des habitats benthiques profonds, pour avoir valeur de référence générale, doit pouvoir être mis en pratique avec précision et efficacité dans les disciplines scientifiques. Ces dernières années, les habitats marins benthiques profonds ont été décrits à partir de données géophysiques et biologiques; les descriptions varient d'un chercheur à l'autre, rendant la comparaison difficile entre les habitats et les populations de différentes régions géographiques. Des données géophysiques obtenues par plusieurs systèmes de détection à distance, et des observations biologiques et géologiques in situ, ont permis d'établir une classification qui est proposée pour décrire les habitats marins benthiques en eau profonde. (C) 1999 Ifremer / CNRS / IRD / Éditions scientifiques et médicales Elsevier SAS

habitat / classification universelle / benthique / gestion des pêcheries

\section{INTRODUCTION}

Remote sensing and large-scale mapping of the seafloor are gaining popularity for assessing habitats and potential impact of human disturbances (such as bottom trawling) on benthic organisms. Because many benthic habitats are defined by their geology (along with depth, chemistry, sedimentology, associated biotic communities and other

* Correspondence and reprints: greene $(\mathrm{mlml}$.calstate.edu 
attributes), geophysical techniques are critical in determining habitat structure and lithology (rock type). However, with the increased use of multidisciplinary techniques (i.e. in situ observations as well as geophysical sensors) and nomenclature (geological, geophysical and biological) to define benthic habitats, it has become apparent that a standard classification scheme is needed to more accurately and efficiently interpret and compare habitats and associated assemblages across geographic regions.

Until recently, assessment of benthic marine habitats and associated biological assemblages has been mostly limited to intertidal and subtidal (i.e. $0-30 \mathrm{~m}$ water depth) regions of the continental shelf. Extensive characterization, mapping and classification schemes have been developed for European shallow coastal biotopes, primarily using Scuba, video surveys, acoustic imaging and geologic sampling in the northeast Atlantic [5-7, 13-15, 24]. In North America, marine geophysical methodologies, such as side-scan sonar, swath bathymetry and seismic reflection profiling, are now being used to investigate benthic habitats in deep water (i.e. $>30 \mathrm{~m}$; [1, 2, 4, $11,12,26-28,31-33])$. These techniques use sound sources of different frequencies to produce images of surface and subsurface features of the seafloor. Reflected sound waves are recorded as seafloor images in plane, areal and cross-section views. Additionally, increased availability and use of underwater video camera systems on remotely operated vehicles (ROVs), occupied submersibles, and benthic sleds have made fine-scale surveys of habitats and associated biological assemblages in deep water more commonplace $[10,30]$.

Although habitat characterization in areas of abrupt bathymetry and deep water is in its infancy, several pioneering studies pertaining to fisheries habitats have been conducted along the continental margin of North America. For example, fisheries habitats have been studied in the Gulf of Maine over the Georges and Stellwagen Banks [16, 17, 27, 28], middle Atlantic Bight [3], and other areas along the east coast of the US $[1,2,26]$. Along the west coast of North America recent investigations of essential benthic habitats of rockfishes have been reported off central California [11, 12, 31, 32, 33], British Columbia [18] and southeast Alaska [20, 21, 29]. Because many of these studies have not yet been widely reported, a workshop on "Applications of Side-scan Sonar and Laser-line Systems in Fisheries Research" was held in an effort to standardize these newly developed methods [19].
Information on benthic habitats is critical to the understanding and prediction of spatial distribution and abundance of many species of fishes. Using geology, geophysics, and biological observations, we describe here a classification scheme that is being applied primarily to benthic habitats of rockfish assemblages in deep water (i.e. $30-300 \mathrm{~m}$ ) along the west coast of North America. We also suggest that this scheme can be developed further as a model for characterizing seafloor habitats elsewhere, and extended to subsurface assemblages that would include the endofauna.

\section{CLASSIFICATION OF HABITATS}

We have adopted a classification scheme developed by Greene et al. [12], which was modified after Cowardin et al. [8] and Dethier [9], and based on remote sensing geophysical and geological techniques that are used to define and map the seafloor in deep water. The interpretations of these geophysical and geological data are groundtruthed or verified using in situ biological and seafloor observations, which is a critical element for habitat classification.

Megahabitats refer to large features that have dimensions from kilometers to tens of kilometers, and larger. Megahabitats lie within major physiographic provinces, e.g. continental shelf, slope and abyssal plain [23]. Although a physiographic province can be a megahabitat, more often these provinces comprise several different megahabitats. Other examples of megahabitats include submarine canyons, seamounts, lava fields, plateaus, large banks, reefs, terraces, and expanses of sediment-covered seafloor.

Mesohabitats are those features having a size from tens of meters to a kilometer. Mesohabitats include small seamounts, canyons, banks, reefs, glacial moraines, lava fields, mass wasting (landslide) fields, gravel, pebble and cobble fields, caves, overhangs and bedrock outcrops. More than one mesohabitat, and similar mesohabitats (in terms of complexity, roughness, and relief), may occur within a megahabitat. Distribution, abundance and diversity of benthic fishes vary among mesohabitats $[1,20$, 25]. Similar megahabitats that include different mesohabitats likely will comprise different assemblages of fishes and, following from this, similar mesohabitats from different geographic regions likely comprise similar fish assemblages (see figure 1, for example).

Macrohabitats range in size from one to ten meters and include seafloor materials and features such as boulders, 


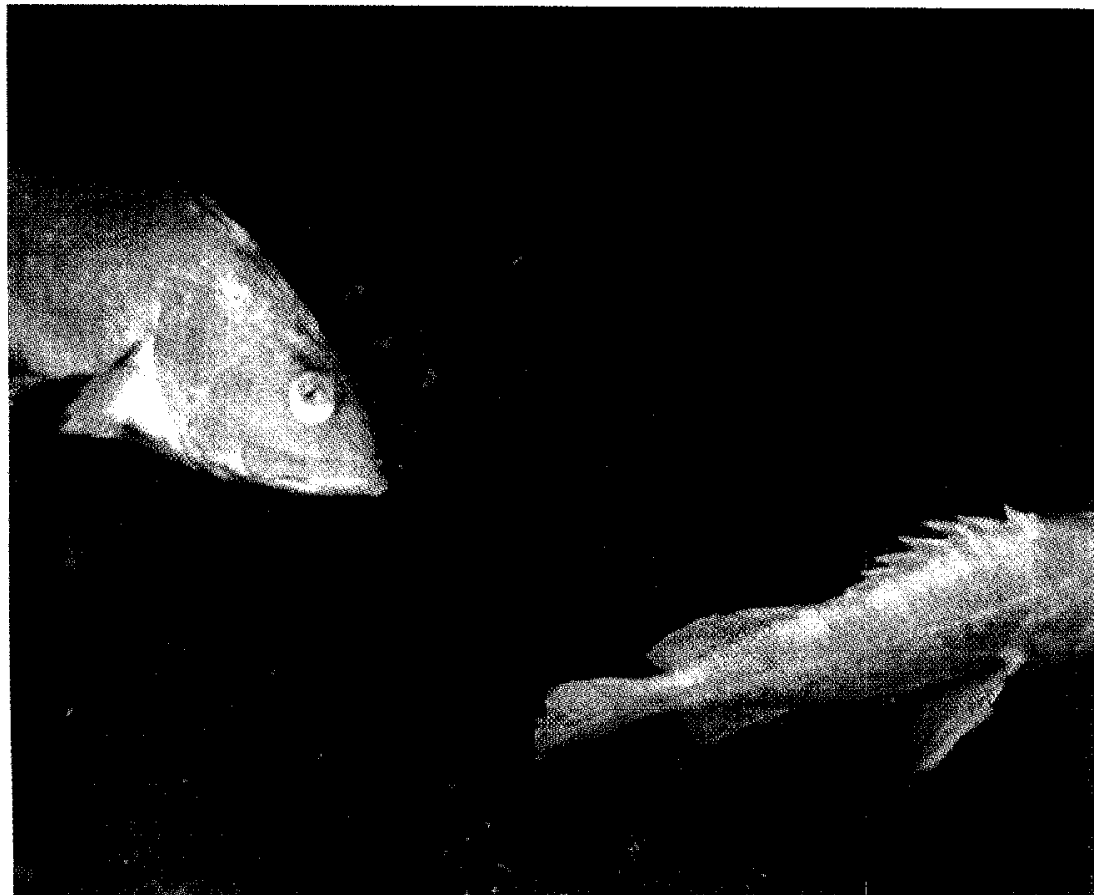

A

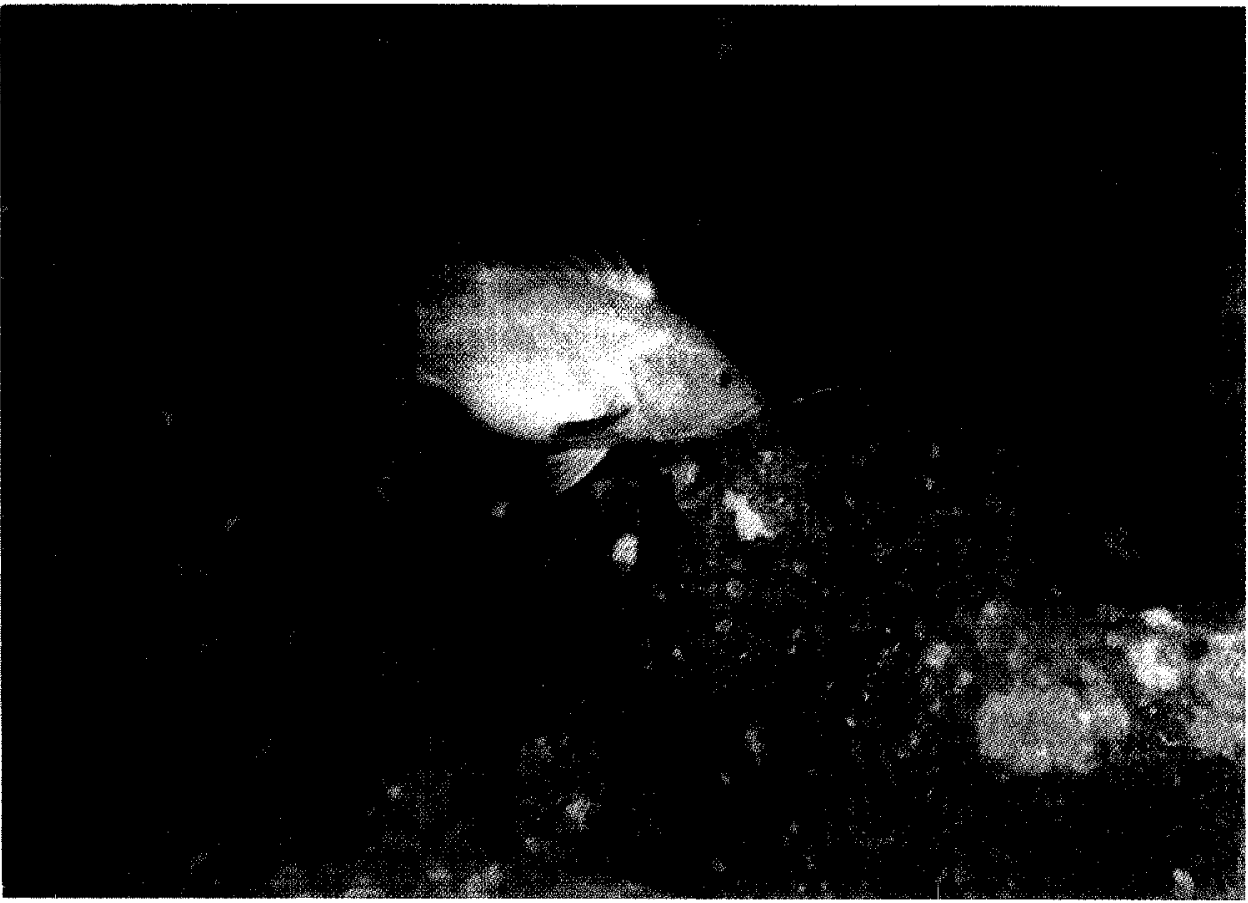

B

Figure 1. Yelloweye rockfish (Sebastes ruberrimus) associated with boulder mesohabitat at (a) base of volcanic cone in the offshore Edgecumbe lava field off southeast Alaska, and (b) in $90 \mathrm{~m}$ water off Pt. Sur, central California.

blocks, reefs, carbonate buildups, sediment waves, bars, crevices, cracks, caves, scarps, sink holes and bedrock outcrops [4, 20]. Mesohabitats can comprise several macrohabitats. Biogenic structures such as kelp beds, corals (solitary and reef-building) and algal mats also represent macrohabitats. 
Microhabitats include seafloor materials and features that are centimeters in size and smaller, such as sand, silt, gravel, pebbles, small cracks, crevices and fractures [3]. Macrohabitats can be divided into microhabitats. Individual biogenic structures such as solitary gorgonian corals (e.g. Primnoa spp), basket sponges (e.g. Spongia spp) and sea anemones (e.g., Metridium spp) form macro- and microhabitats.

We propose the following standard classification structure:

\subsection{System}

(based on salinity and proximity to the seafloor)

We have developed this habitat classification scheme for the Marine Benthic System, as compared with Estuarine or Freshwater and Pelagic, Epipelagic, etc. systems.

- Marine Benthic

Subsystem (mega- and mesohabitats based on physiography and depth) Depth intervals are relevant to fisheries assessment and management.

(see figure 2 for an illustration of several megahabitats)

- Continental Shelf

Intertidal (salt spray to extreme low water)

Shallow Subtidal (water depth $=030 \mathrm{~m}$ )

Outer (water depth $=30-200 \mathrm{~m}[\sim$ location of shelf break])

- Continental Slope

Upper (water depth $=200-500 \mathrm{~m})$

Intermediate (water depth $=500-1000 \mathrm{~m}$ )

Lower (water depth $=1000+\mathrm{m}$ )

- Continental Rise (water depth $-3000-5000 \mathrm{~m}$ )

- Abyssal Plain $(\sim$ water depth $=5000+\mathrm{m})$

- Trenches $(\sim$ water depth $=3000-11000 \mathrm{~m})$

- Submarine Canyons

Head (water depth $=<100 \mathrm{~m}$ )

Upper (water depth $=100-300 \mathrm{~m}$ )

Middle (water depth $=300-500 \mathrm{~m}$ )

Lower $($ water depth $=500-1000+\mathrm{m}$ )

- Seamounts

Top

Flank

Base
Class (meso- or macrohabitats based on seafloor morphology) (see figure 3 for an example of mesohabitats) e.g.:

- Bar

- Sediment Wave

- Bank

- Moraine

- Cave, Crevice (ragged features)

- Sink

- Debris Field, Slump, Block Glide, Rockfall

- Groove, Channel (smooth features)

- Ledge

- Vertical Wall

- Pinnacle

- Mound, Buildup, Crust (> $3 \mathrm{~m}$ in size)

- Slabs

- Reef (carbonate feature)

- Biogenic

- Nonbiogenic

- Scarp, Scar

- Terrace

- Vent

- Artificial Structure (wreck, breakwater, pier)

- Lava Field

- Compression Ridge

- Lava T'ube

- Crater

- Lava flow

Subclass (macro- or microhabitats based on substratum textures) (see figure 4 for an example of macro- and microhabitats) e.g.:

- Organic Debris (coquina; shell hash; drift algae)

- Mud (clay to silt; grain size $<0.06 \mathrm{~mm}$ )

- Sand (grain size $=0.06-2 \mathrm{~mm}$ )

- Gravel (grain size $=2-4 \mathrm{~mm}$ )

- Pebble (grain size $=2-64 \mathrm{~mm}$ )

- Cobble (grain size $=64-256 \mathrm{~mm}$ )

- Boulder (grain size $=0.25-3.0 \mathrm{~m}$ )

- Mixed Sediment (combinations of all of the above)

- Bedrock 


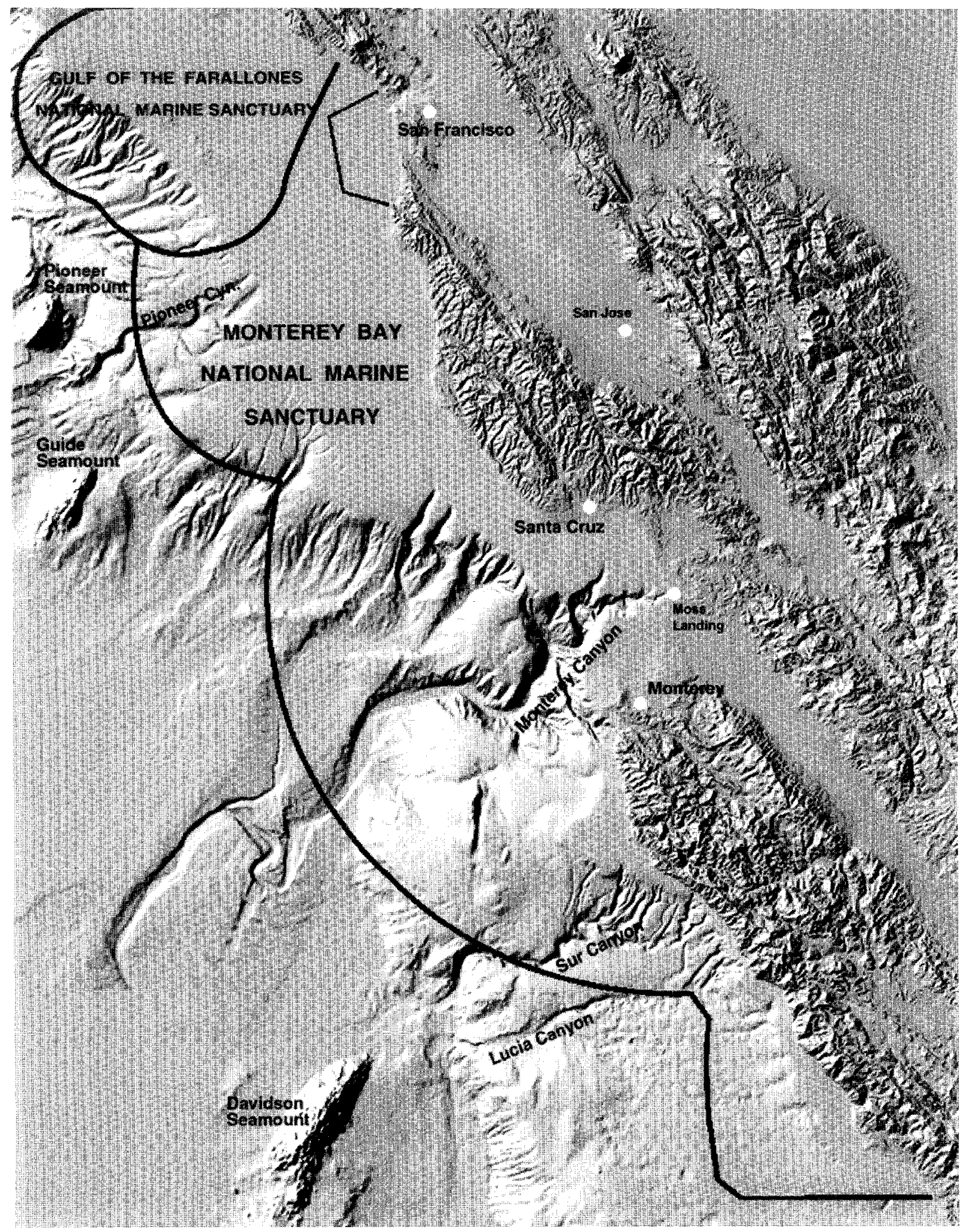

Figure 2. Physiographic map (based on NOAA SeaBean swath bathymetric data) of central California megahabitats, including submarine canyon, continental slope and shelf, and seamounts. 
H.G. GREENE et al.

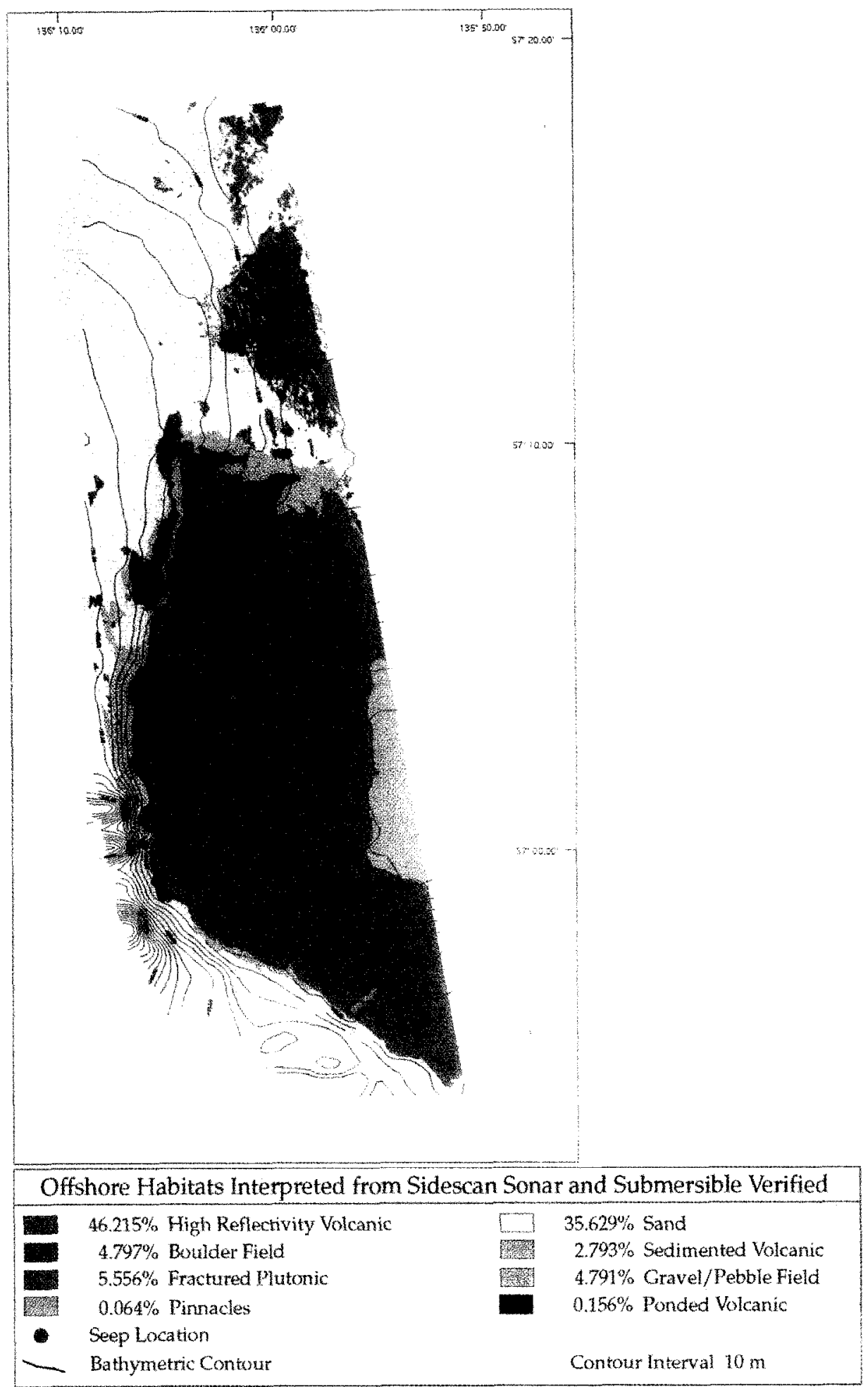

Figure 3. Geological map of the offshore Edgecumbe lava field, including lava flows, moraines, volcanic cones and other mesohabitats. Map based on AMS $150 \mathrm{kHz}$ side scan sonar and interferometry bathymetric data. 


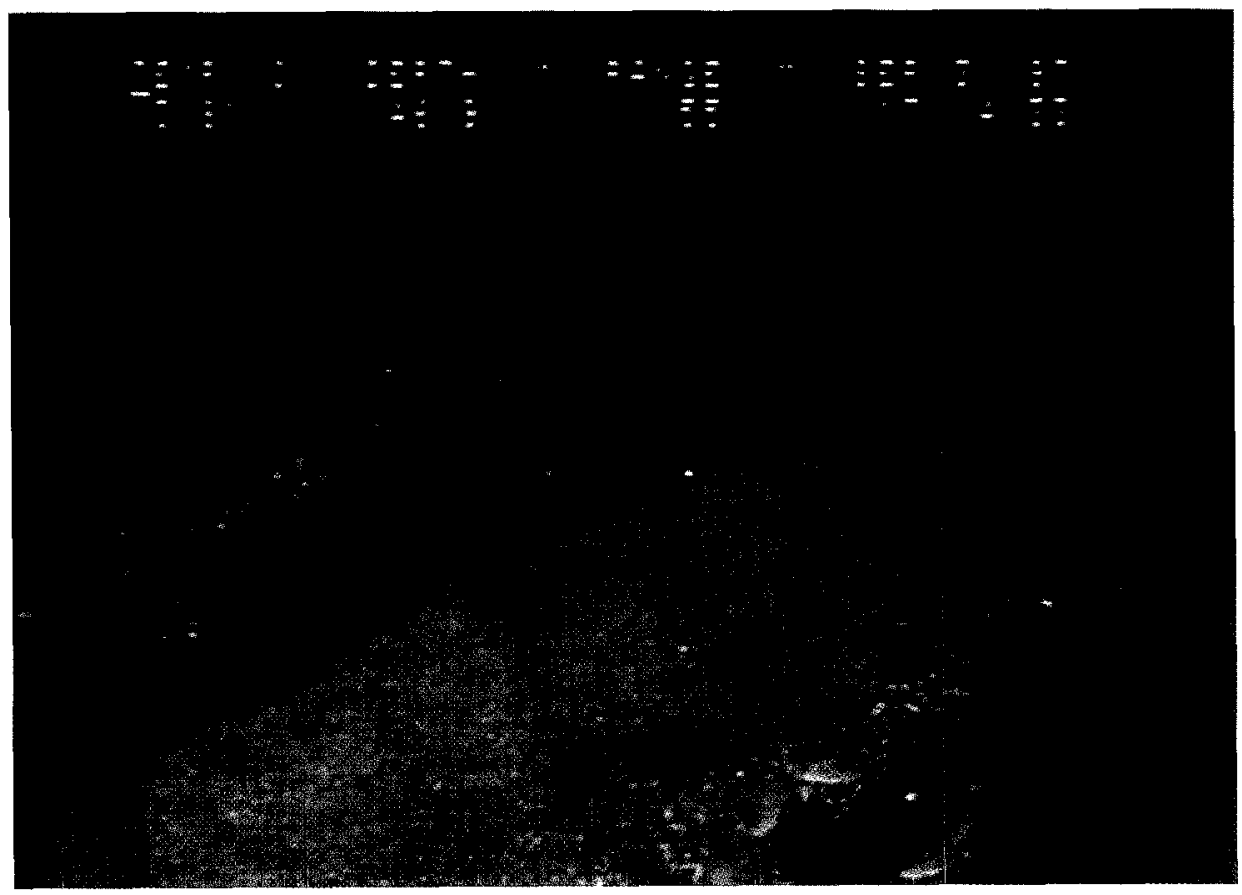

A

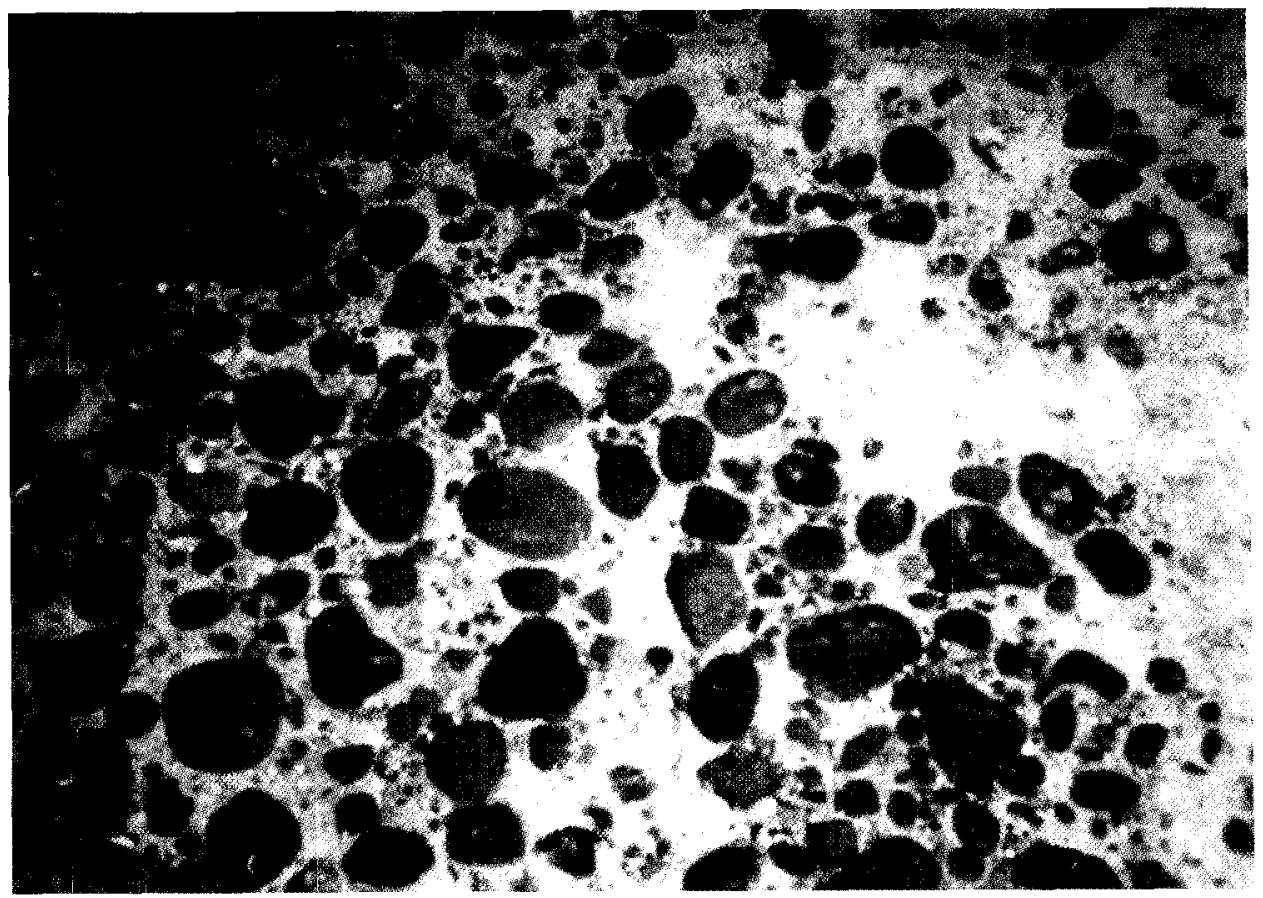

B

Figure 4. (a) Sand wave macrohabitat with speckled sanddabs (Citharichthys stigmaeus) in Big Creek Ecological Reserve, central California (note: 20-cm dual laser spots in center of photograph as scale), and (b) pebble microhabitat in offshore Edgecumbe lava field, southeast Alaska.

- Igneous (granitic; volcanic)

- Metamorphic

- Sedimentary
Subclass (macro- and microhabitats based on slope) e.g.:

- Flat $\left(0-5^{\circ}\right)$

- Sloping $\left(5-30^{\circ}\right)$ 


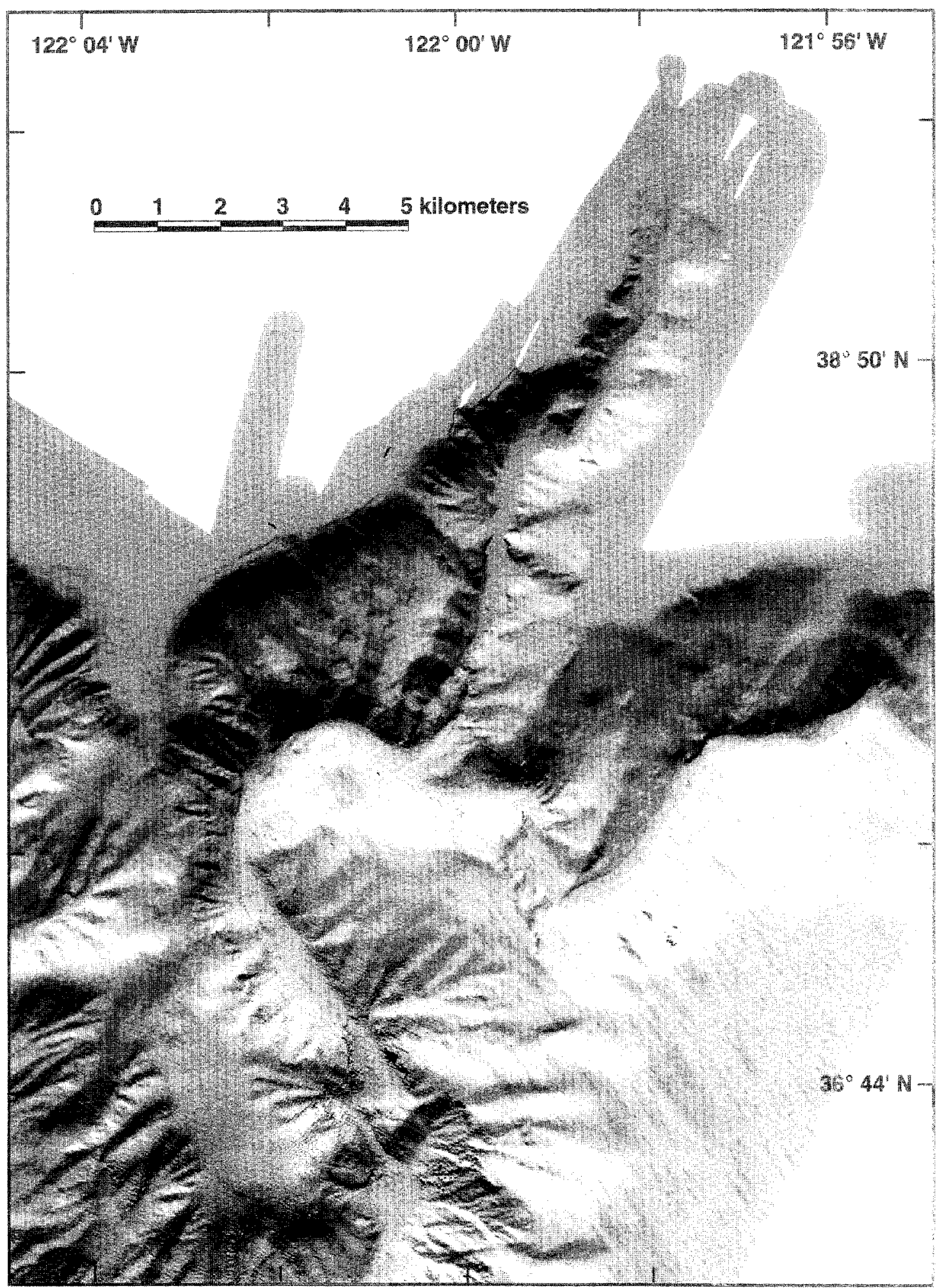

Figure 5. Bathymetric image of mega- and mesohabitats in Soquel Canyon. These data were recently cullected by the Munterey Bay Aquarium Research Institute using a Simrad EM $300 \mathrm{kHz}$ swath mapping system. 


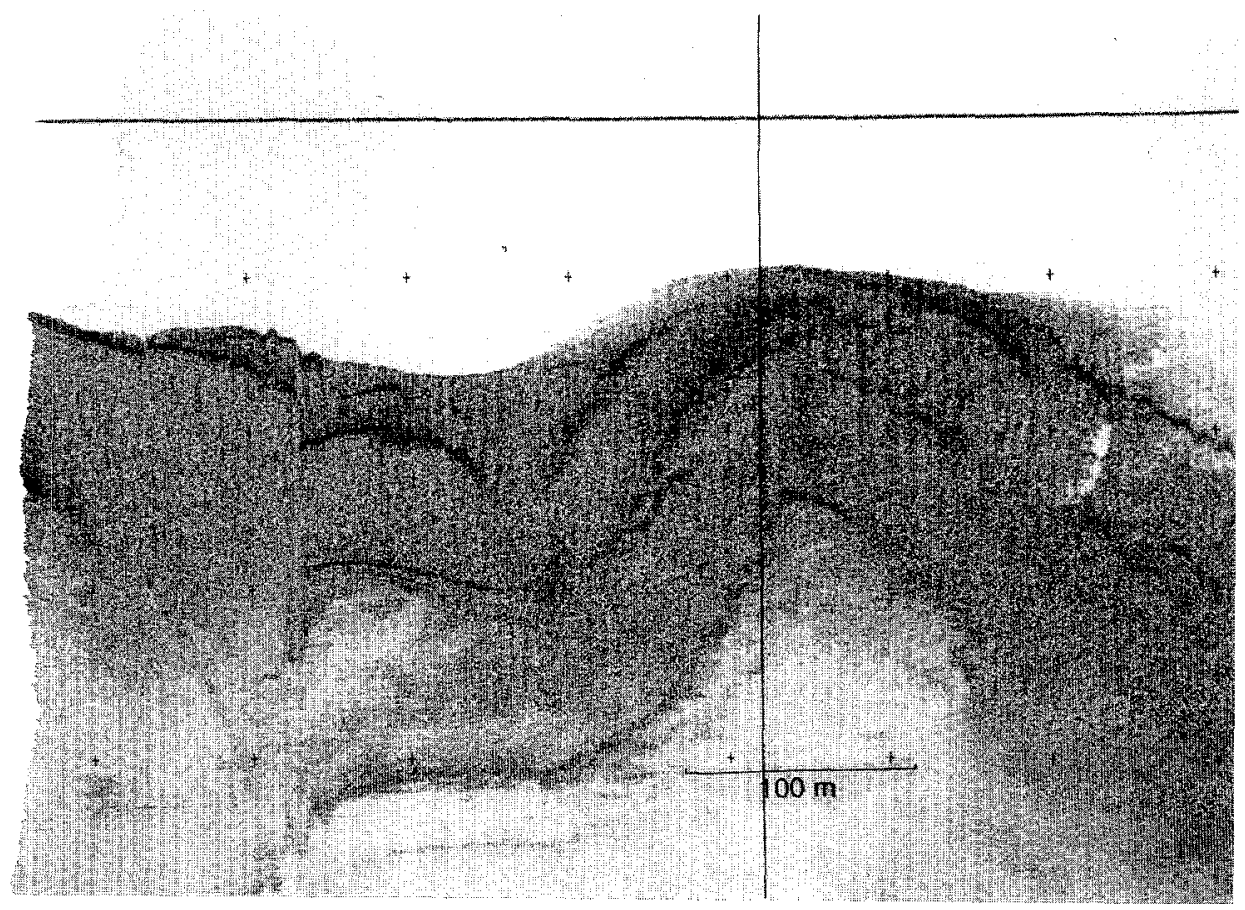

Figure 6. Side scan sonar $(100 \mathrm{kHz}$ system) image of differentially eroded sedimentary rock outcrop along a wall of Soquel Canyon, Monterey Bay, California.

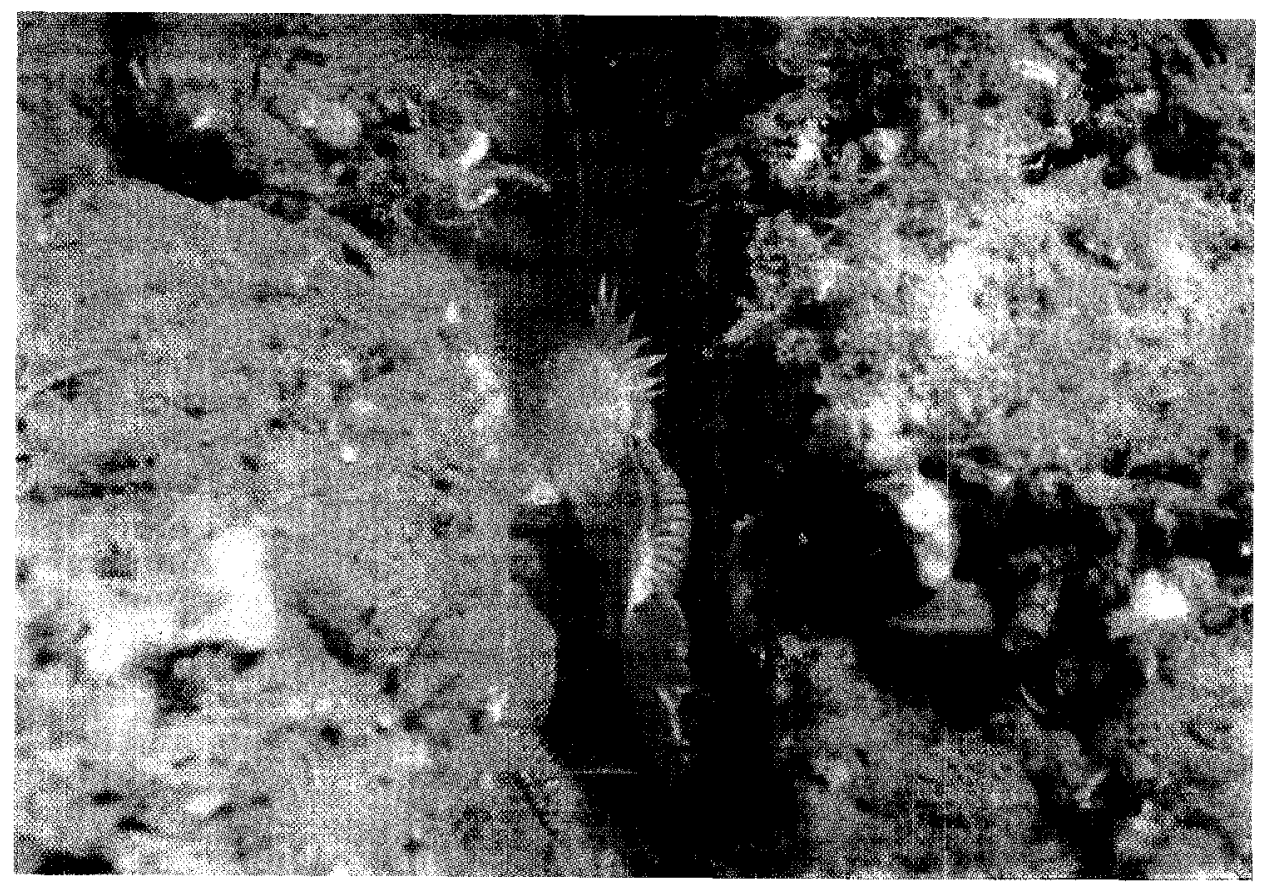

Figure 7. Crevice in the Pliocene Purisima formation that has been differentially eroded alorig the walls of Suquel Canyon, Monterey Bay, California. Photograph taken from the submersible Delta in $180 \mathrm{~m}$ water. This is typical habitat of adult greenspotted rockfishes (Sebastes chlorostictus). 
A

Dive Alea 11

Volcanic Enmales of the Submarino Mount Hagcumbe lava ficld

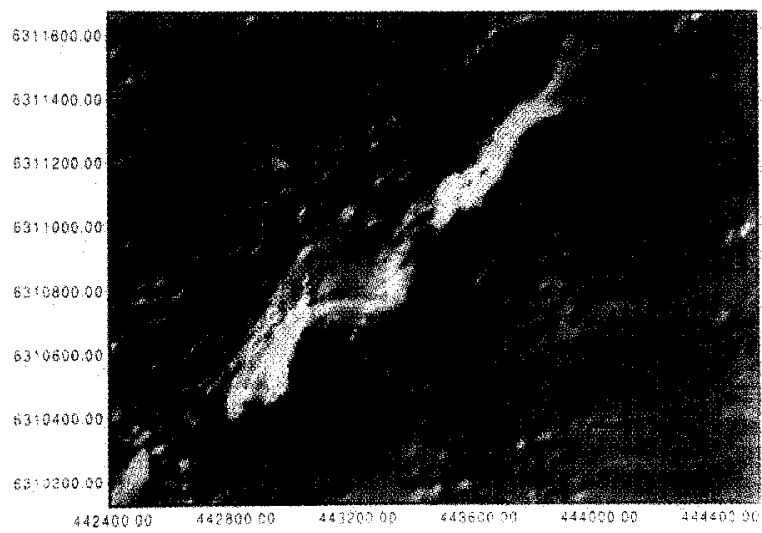

B Dive Area 11
Volcanic Pinnacles of the Submarine
Mt. Edgecumbe Lava Field

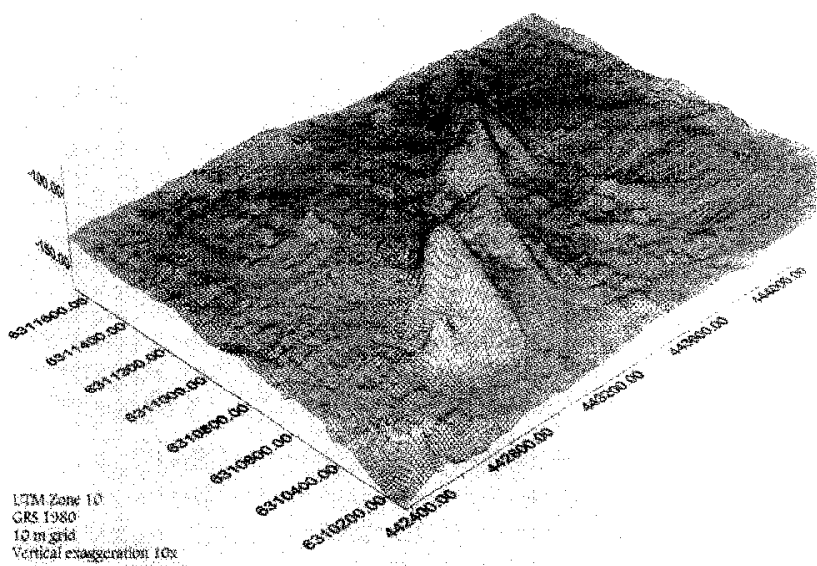

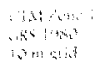

Figure 8. Bathymetric (a) shaded-relief and (b) net mesh diagrams of pinnacle (volcanic cones) mesohabitats ocated on the southern end oi the offshore Edgecumbe lava field off Sitka, Alaska. Images produced from AMS $150 \mathrm{kHz}$ side scan sonar.

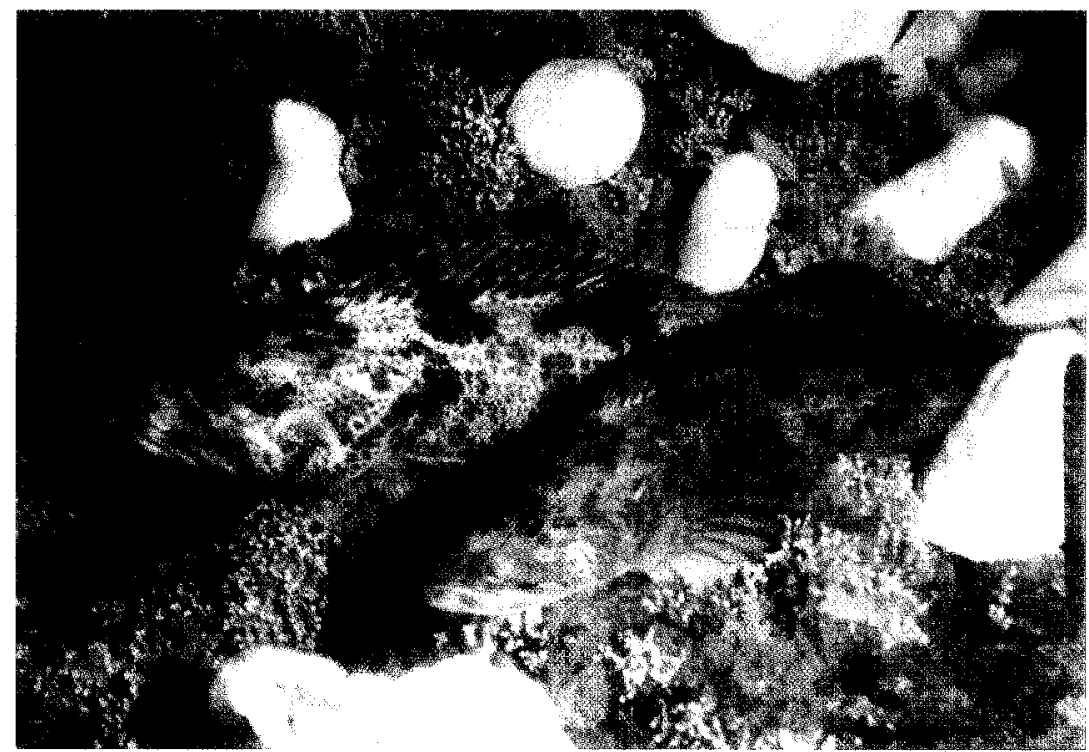

Figure 9. Biological microhabitats of algae and sea anemones with lingcod (Ophiodon elongatus) and young of the year rockfish (Sebastes spp.) on top of rock pinnacle mesohabitat (see figure 8 for location). Photograph taken from submersible Delta. Note lingcod (40 cm total length) for scale.

- Steeply Sloping $\left(30-45^{\circ}\right)$

- Vertical $\left(45-90^{\circ}\right)$

- Overhang $\left(>90^{\circ}\right)$

\subsection{MODIFIERS}

\section{- for bottom morphology}

- regular (continuous homogeneous bottom with little relief) 
- irregular (continuous non-uniform bottom with relief $1-10 \mathrm{~m}$ in height)

- hummocky (uniform bottom with mounds or depressions $0-3 \mathrm{~m}$ in height or depth)

- structure (fractured, faulted, folded)

- outcrop (amount of exposure)

- bedding

- massive

- friable

\section{- for bottom deposition}

- consolidation (unconsolidated, semi-consolidated, wellconsolidated)

- erodability (uniform, differential)

- sediment cover

- dusting (thickness of layer $<1 \mathrm{~cm}$ )

- thin (thickness of layer $=1-5 \mathrm{~cm}$ )

- thick (thickness of layer $>5 \mathrm{~cm}$ )

\section{- for bottom texture}

- voids (percentage volume occupied by clast or rock)

- sorting (i.e. well sorted; poorly sorted)

- packing (i.e. well packed; poorly packed)

- density (particle concentration)

- occasional

(random occurrence of feature, e.g. boulder)

- scattered (feature covers $10-50 \%$ of area)

- contiguous (features are close to touching)

- pavement (features are touching everywhere)

- lithification

- jointing

- clast (rock) roundness

- clast shape

- blucky

- lensoidal

- boitroidal (e.g. pillow lava)

- needle-like

- angular

\section{-'for physical processes}

- currents

$$
\text { - winnowing }
$$

- scouring or lag deposits

- sediment trail

- wave activity

- upwelling

- seismic (earthquakes, shaking and fault rupture)

- for chemical processes

- vent chemistry (sulfur, methane, freshwater, $\mathrm{CO}_{2}$ )

- cementation

-weathering or oxidation (fresh to highly weathered)

\section{- for biological processes}

- bioturbation (tracks, trails, burrows, excavation)

- cover of encrusting organisms

- continuous ( $>70 \%$ )

- patchy $(20-70 \%$ cover $)$

- little to no cover $(<20 \%)$

- communities (examples of conspicuous species)

- sea anemones

- crinoids

- vase sponges

- coralline algae

- kelp understory

- sea grasses

- kelp forest

- for anthropogenic processes (examples of human disturbance)

- artificial reefs

- dredge spoil piles

- trawl and dredge tracks

- discarded and lost fishing gear

\section{EXAMPLES OH MARINE BENITHIC HABITATS}

Soquel submarine canyon in Monterey Bay, California has been described using our habitat classification scheme:

A megahabitat comprising upper submarine canyon (100-300 m), steeply sloping $\left(30-45^{\circ}\right)$ walls, and locally including mesohabitats of vertical walls $\left(80-90^{\circ}\right)$ with landslide morphology (slump scarps and debris field; figure 5). Macro- and mesohabitats include well-bedded, 


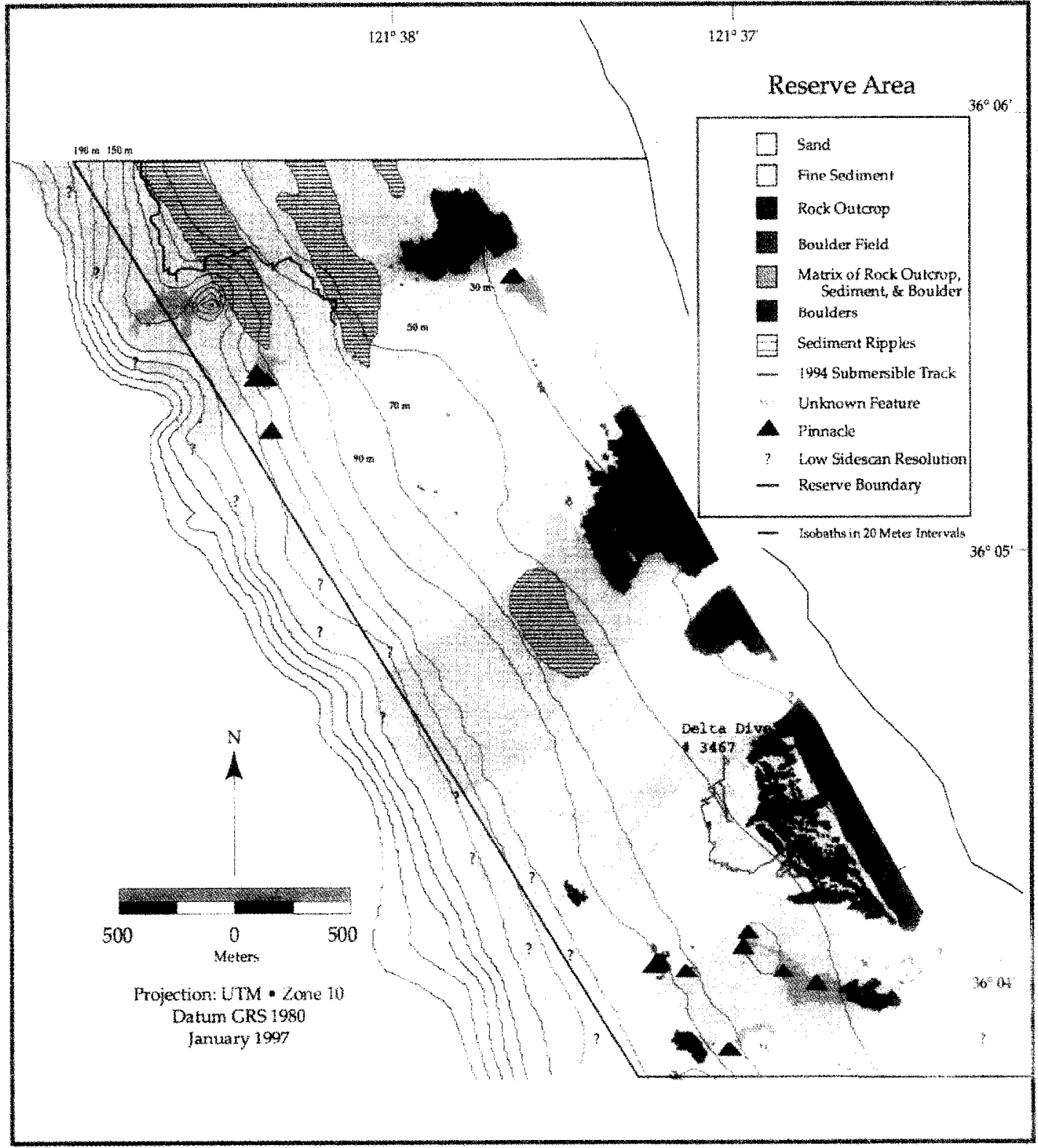

Figure 10. Map of mega- and mesohabitats in the Big Creek Ecological Reserve off central California, as interpreted from $100 / 500 \mathrm{kHz}$ EG\&G side scan sonar images.

friable outcrops of sandstone, mudstone and coquina. Differentially eroded beds (figure 6) along the canyon walls form overhangs $\left(>90^{\circ}\right)$ and crevices (figure 7 ); landslide debris produces irregular seafloor conditions consisting of scattered blocky boulders of sandstone interspersed with a fairly bioturbated mud seafloor. Landslide debris contains $40 \%$ boulders, $20 \%$ cobble field and $40 \%$ mud.

These descriptions of habitats in relatively decp water, together with the quantitative analyses of associated fish assemblages, are valuable in predicting community structure and evaluating changes to that structure, as well as in applying small scale species-habitat relationships to broader scale fishery resource surveys.

An example from a volcanic lava field that is essential habitat for yelloweye rockfishes (Sebastes ruberrimus) off southeast Alaska has been described using our classification scheme:

Lava ficld mcgahabitat on continental shelf in intermediate water depths $(30-200 \mathrm{~m})$. Meso- and macrohabitats 
A

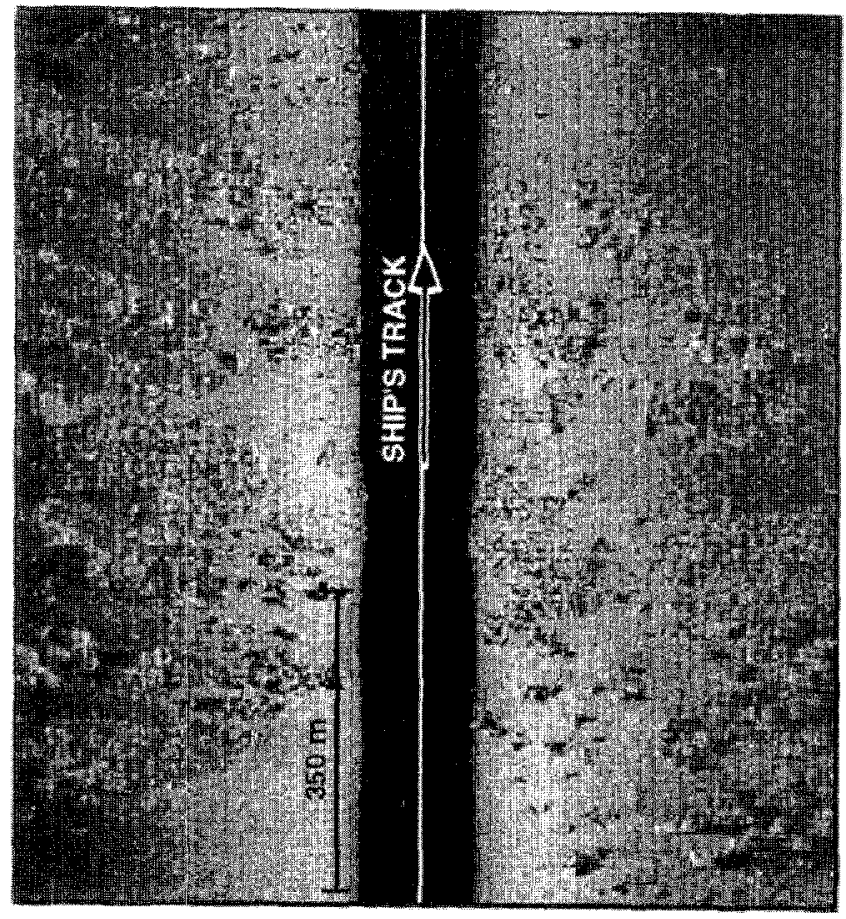

B
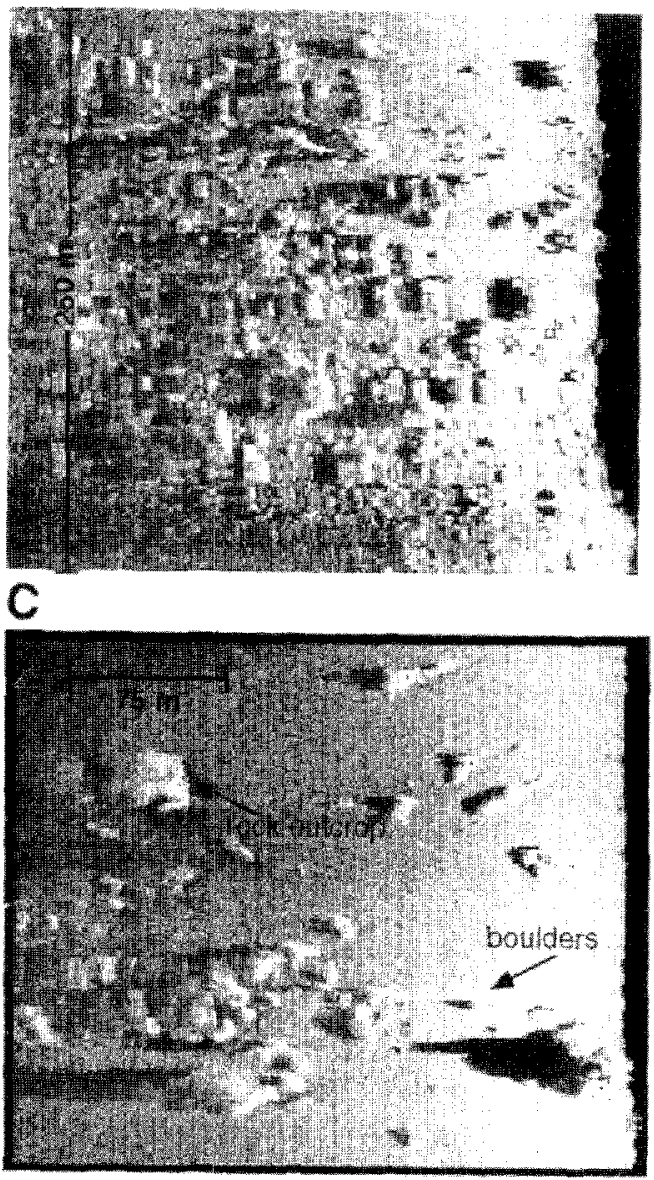

D

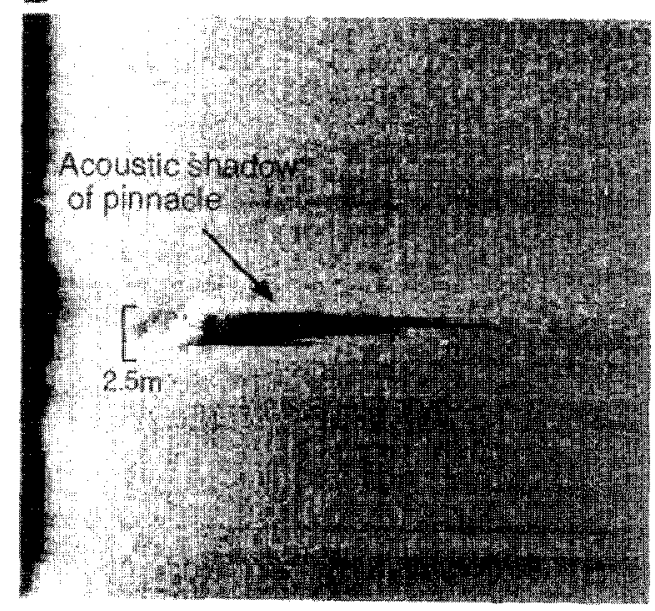

Figure 11. Side-scan sonar images (reversed shading) of the seafloor in and around the Big Creek Ecological Reserve. (a) Boulder fields intermixed with fine sediments over a distance of $1 \mathrm{~km}$ in $50 \mathrm{~m}$ water depth. Sonar frequency: $100 / 500 \mathrm{kHz}$; total swath width: $800 \mathrm{~m}$. (b) Example of hummocky rock outcrop in southern part of study site. (c) Matrix of rock outcrop, individual boulders, and fine sediment. (d) Rock pinnacle, up to $7 \mathrm{~m}$ high and $2.5 \mathrm{~m}$ in diameter, surrounded by fine sediment in $35 \mathrm{~m}$ water depth located south of the reserve. After [33].

include pinnacles (volcanic cones), ledges, vertical walls, collapsed lava tubes, compression ridges, caves and crevices, moraines and extensive sand fields (figure 3). The lava field is irregular (1-3 m relief) with both a'a' and pahoihoi lava flows. Pinnacle mesohabitat (figure 8) has a large boulder apron macrohabitat at the base, with 
vertical walls of columnar basalt forming the flanks, and an irregular top that supports a microhabitat of anemones, hydrocorals, bryazoans, and redtree coral (figure 9).

Evidence from in situ observations of fish abundance and distribution, combined with extensive benthic habitat mapping, led to our recognition that the pinnacle area is a rare and highly productive feature, providing habitat for breeding, spawning, growth, and maturation of a variety of species. In 1997, the area was classified by the National Marine Fisheries Service, the Alaska Department of Fish and Game, and the International Pacific Halibut Commission as a permanent no-take marine reserve for groundfish (those species associated with the seafloor; [22]). This is the first marine reserve in the state of Alaska that is closed to all harvesting of groundtish. Anchoring also is prohibited in an effort to protect habitat.

A final example of a marine benthic megahabitat is described for an area of the Big Sur coastline off central California, within the Big Creek Ecological Research Reserve:

Flat megahabitat on continental shelf in shallow to intermediate water depths $(0-100 \mathrm{~m}$; figure 10$)$. Mesohabitats include sand waves, sand stringers and cobble patches interspersed with rock outcrops; isolated boulders and pinnacles are examples of macrohabitats (figure 11).

Characterizations of benthic habitats are critical steps in evaluating the effectiveness of the Big Creek Ecological Reserve at protecting and enhancing coastal fishery resources. These characterizations and maps of bottom types have directed the efforts to assess the fishes and their habitat associations within the reserve, and provide the basis for long-term monitoring and management of marine resources in this area.

\section{CONCLUSIONS}

Geophysical techniques that help identify and define large-scale marine benthic features are valuable in appraising essential habitats of marine benthic fish assemblages. Interpretation and verification of those features identified from side scan sonar, swath bathymetry backscatter imagery, and seismic reflection profiles are critical in characterizing these habitats. We have developed a classification scheme that should be useful in standardizing descriptions of such habitats in deep water. This classification scheme is applicable to data collected with several types of sensor systems that are now being used to characterize deep-water habitats of invertebrate and vertebrate fauna.

\section{Acknowledgements}

This work was supported in part by the National Oceanic and Atmospheric Administration (NOAA) West Coast and Polar Regions Center for the National Undersea Research Program (Project Nos. CA-92-2, CA-93-4; NA77FM0209), National Marine Fisheries Service (Project No. 11-454), Monterey Bay National Marine Sanctuary, and California Sea Grant College Program (Project No. R/BC-1). The US National Science Foundation, Division of International Programs, Opportunities for Scientists and Engineers supported the presentation of this information at the workshop in Noumea, New Caledonia and preparation of this manuscript (Award Nos. NSF-96-14 and 9731001). This manuscript was improved by the comments of four anonymous reviewers, whose constructive suggestions are appreciated.

\section{REFERENCES}

[1] Able K.W., Twichell D.C., Grimes C.B., Jones R.S., Sidescan sonar as a tool for detection of demersal fish habitats, Fish. Bull. (U.S.) 85 (1987) 725-736.

[2] Able K.W., Grimes C.B., Twichell D.C., Jones R.S., Side-scan sonar as a tool for determination of demersal fish habitat use patterns on the continental shelf, in: O'Connell T., Wakefield W. (Eds.) Applications of Side-scan Sonar and Laser-line Systems in Fisheries Research, Alaska Fish and Game Sp. Publ. No. 9, 1995, pp. 8-9.

[3] Auster P.J., Malatesta R.J., LaRosa S.C., Cooper R.A., Stewart L.L., Microhabitat utilization by the megafaunal assemblage at a low relief outer continental shelf site, Middle Atlantic Bight, USA, J. NW Atl. Fish. Sci. 11 (1991) 59-69.
[4] Auster P.J., Lewis R.S., Wahle L.C., Babb I.G., Malatesta R.J., The use of side-scan sonar for landscape approaches to habitat mapping, in: O'Connell T., Wakefield W. (Eds.), Applications of Side-scan Sonar and Laser-line Systems in Fisheries Research, Alaska Dept., Fish and Game Sp. Publ. No. 9, 1995, pp. $1-7$.

[5] Connor D.W., Hiscock K., Foster-Smith R.L., Covey R., A classification system for benthic biotopes, in: Eleftheriou A., Ansell A.D., Smith C. (Eds.), Biology and Ecology of Shallow Coastal Waters, Proceedings 28th European Marine Biology Symposium, Olsen and Olsen, Fredensborg, 1995, pp. 155165.

[6] Connor D.W., Brazier D.P., Hill T.O., Northern K.O., Marine nature conservation review: marine biotope classification for 
Britain and Ireland, Vol. 1, Littoral biotopes, Version 97.06, Joint Nature Conservation Committee Report 229 (1997).

[7] Connor D.W., Dalkin M.J., Hill T.O., Holt R.H.F., Sanderson W.G., Marine nature conservation review: marine biotope classification for Britain and Ircland, Vol. 2, Sublittoral biotopes, Version 97.06, Joint Nature Conservation Committee Report 230 (1997).

[8] Cowardin L.M., Carter V., Golet F.C., LaRoe E.T., Classification of wetlands and deepwater habitats of the United States, U.S. Fish and Wildlife Service, Dept. Interior, FWS/OBS79/31, 1979, $131 \mathrm{p}$.

[9] Dethier M.N., Classifying marine and estuarine natural communities: an alternative to the Cowardin system, Nat. Areas J. 12 (1992) 90-100.

[10] Greene H.G., Stakes D.S., Orange D.L., Barry J.P., Robison B.H., Application of an ROV in geologic mapping of Monterey Bay, California, USA, Proc. Am. Acad. Underw. Sci. 13th Annual Scientific Diving Symposium, Pacific Grove, CA, 1993, pp. 17-32.

[11] Greene H.G., Yoklavich M.M., Barry J.P., Orange D.L., Sullivan D.E, Cailliet G.M., Geology and related benthic habitats of Monterey Canyon, central California, EOS Trans. Am. Geoph. Un. Suppl. 75:3 (1994) 203.

[12] Greene H.G., Yoklavich M.M., Sullivan D., Cailliet G.M., A geophysical approach to classifying marine benthic habitats: Monterey Bay as a model, in: O'Connell T., Wakefield W. (Eds.), Applications of Side-scan Sonar and Laser-line Systems in Fisheries Research, Alaska Fish and Game Sp. Publ. No. 9, 1995, pp. 15-30.

[13] Hiscock K., Subtidal rock and shallow sediments using diving, in: Baker J.M., Wolff W.J. (Eds.), Biological Surveys of Estuaries and Coasts, Cambridge Univ. Press, Cambridge, 1987 , pp. 198-237.

[14] Hiscock K., Britain's marine habitats and species, in: Hiscock K. (Ed.), Marine Nature Conservation Review: Rational and Methods, Joint Nature Conservation Committee, 1997, pp. 2343.

[15] Kinne O. (Ed.), Marine Ecology: A Comprehensive, Integrated Treatise on Life in Occans and Coastal Waters, Volume $V$ Ocean Management, Part 1, John Wiley and Sons, New York, 1982, $642 \mathrm{p}$.

[16] Lough R.G., Valentine P.C., Potter D.C., Auditore P.J., Bolz G.R., Neilson J.D., Perry R.I., Ecology and distribution of juvenile cod and haddock in relation to sediment type and bottom currents on eastern Georges Bank, Mar. Ecol. Progr. Ser. 56 (1989) $1 \cdots 12$.

[17] Lough R.G., Valentine P.C., Brown C.L., Michaels W.L., Maps showing the distribution of juvenile cod in telation to the sedimentary environment of eastern Georges Bank, U.S. Geological Survey Open-File Report 92-566, 1992.

[18] Matthew K.R., Richards L.R., Rockfish (Scorpaenidae) assemblages of trawlable and untrawlable habitats off Vancouver Island, B.C., North Am. J. Fish. Manage. 11 (1991) 312318.
[19] O'Connell T., Wakefield W. (Eds.), Applications of Side-scan Sonar and Laser-line Systems in Fisheries Research, Alaska Depl, Fish and Game Sp. Publ. No. 9, 1995, 50 p.

[20] O'Connell V.M., Carlile D.W., Habitat-specific density of adult yelloweye rockfish Sebastes ruberrimus in the eastern Gulf of Alaska, Fish. Bull. (U.S.) 91 (1993) 304-309.

[21] O'Connell V.M., Carlile D.C., Wakefield W.W., Greene H.G., Habitat-based assessments of a long-lived species in the Gulf of Alaska: implications for commercial fisheries management, Marine Benthic Habitats Conference, Program and Abstracts, Noumea, New Caledonia, (Ifremer/Orstom), 1997, pp. 86.

[22] O'Connell V., Wakefield W.W., Greene H.G., The use of a notake marine reserve in the eastern Gulf of Alaska to protect essential fish habitat, in: Yoklavich, M.M. (Ed.), Marine Harvest Refugia For West Coast Rockfish: A Workshop, NOAA Technical Memorandum NO $\Lambda$-TM-NMFS-SWFSC-255, 1998, pp. 125-132.

[23] Shepard F.P., Submarine Geology (3rd ed.), Harper and Row, New York, 1963, 557 p.

[24] Sotheran I.S., Foster-Smith R.L., Davies J., Mapping of marine benthic habitats using image processing techniques within a raster-based Geographic Information System, Est. Coast. Shelf Sci. 44 (Suppl. A) (1997) 25-31.

[25] Stein D.L., Tissot M.A., Hixon M.A., Barss W., Fish-habitat associations on a deep reef at the edge of the Oregon continental shelf, Fish. Bull. (U.S.) 90 (1992) 540-551.

[26] Twichell D.C., Able K.W., Bathymetry, sidescan sonar image, and surficial geological interpretation of the inner shelf off Little Egg Inlet, New Jersey, U.S. Geological Survey Miscellaneous Field Studies Map, MAP MF-2221 (1993).

[27] Valentine P.C., Lough R.G., The sea floor environment and the fishery of eastern Georges Bank, the influence of geologic and oceanographic environmental factors on the abundance and distribution of fisheries resources of the northeastern United States continental shelf, U.S. Geological Survey Open-File Report 91-439, 1991.

[28] Valentine P.C., Schmuck C.A., Geological mapping of biological habitats on Georges Bank and Stellwagen Bank, Gulf of Maine region, in: O'Connell T., Wakefield W. (Eds.), Applications of Side-scan Sonar and Laser-line Systems in Fisheries Research, Alaska Dept, Fish and Game Sp. Publ. No. 9, 1995, pp. 31-40.

[29] Wakefield W.W., Greene H.G., O'Connell V.M., Gann J., The offshore Edgecumbe lava field, southeast Alaska: geological and habitat characterization of a commercial fishing ground, EOS Transactions Am. Geophys. Un. 76 (3) (1996) 95.

[30] Yoklavich M.M., Applications of side-scan sonar and in-situ submersible survey techniques to marine fisheries habitat research, in: Boetlert G.W., Schumacher J.D. (Eds.), Changing Oceans and Changing Fisheries: Environmental Data for Fisheries Research and Management, NOAA Technical Memorandum NOAA-TM-NMFS-SWFSC-239, 1997, pp. 140-141.

[31] Yoklavich M.M., Greene H.G., Moreno G., Cailliet G.M., Sullivan D., The importance of small-scale refugia to deep water rockfishes (Sebastes sp.) - a pilot study in Soquel 
H.G. GREENE et al.

Canyon, Monterey Bay, CA, EOS Trans. Am. Geophys. Un. 73 (43) (1992) 318.

[32] Yoklavich M.M., Cailliet G.M., Greene H.G., Sullivan D., Interpretation of side-scan sonar records for rockfish labitat analysis: examples from Monterey Bay, in: O'Connell, T., Wakefield W. (Eds.), Applications of Side-scan Sonar and
Laser-line Systems in Fisheries Research, Alaska, Fish and Game Sp. Publ. No. 9, 1995, pp. 11-14.

[33] Yoklavich M.M., Starr R., Steger J., Greene H.G., Schwing F., Malzone C., Mapping benthic habitats and ocean currents in the vicinity of central Califonia's Big Creek Ecological Reserve NOAA Techn. Memor. NOAA-TM-NMFS-SWFSC$245,1997,52 \mathrm{p}$ 